\title{
KIT PRAKTIKUM MEDIA PEMBELAJARAN MATERI CAMPURAN DAN LARUTAN UNTUK PESERTA DIDIK TUNANETRA DI SMPLB
}

\section{Wara Mulyaning Utami' ${ }^{1}$, Achmad Lutfi ${ }^{2}$}

1,2 Jurusan Kimia, Universitas Negeri Surabaya, Surabaya, Indonesia

\author{
A R T I C L E I N F O \\ Article history: \\ Received 29 Desember \\ 2020 \\ Received in revised form 19 \\ Januari 2021 \\ Accepted 25 Maret 2021 \\ Available online 25 April \\ 2021
}

Kata Kunci:

Pengembangan, KIT

Praktikum, Tunanetra

Keywords:

Blended Learning,

Google Classroom

\begin{abstract}
A B S T R A K
Pembelajaran IImu Pengetahuan Alam menekankan pada pemberian pengalaman langsung untuk mengembangkan kompetensi peserta didik agar manpu menjelajahi dan memahami alam sekitar melalui metode ilmiah yang ditekankan dalam bentuk $5 \mathrm{M}$. Penelitian ini bertujuan mengembangkan suatu komponen instrumen terpadu atau disebut dengan KIT untuk mempermudah proses pengamatan atau percobaan peserta didik tunanetra pada SMPLB dalam menunjang pembelajaran materi campuran dan larutan yang valid, efektif dan praktis. Kompetensi dasar peserta didik tunanetra kelas sembilan SMPLB meminta peserta didik tunanetra dapat melakukan pengamatan maupun percobaan pada materi campuran dan larutan namun tidak selaras dengan ketersediaan media pembelajaran. Penelitian ini menggunakan pendekatan research and development (R\&D) yang bertujuan untuk mengembangkan dan memvalidasi perangkat yang digunakan di sekolah agar bekerja siap pakai efektif, serta praktis. Dihasilkan perangkat pembelajaran Campuran dan Larutan yang valid, efektif, dan praktis pada peserta didik
\end{abstract} tunanetra kelas IX SMPLB. Hal ini diperoleh berdasarkan hasil uji ahli media, materi, dan guru pengajar peserta didik tunanetra. Hasil menguji dilakukan pada lima anak tunanetra. Respon diambil dari peserta didik tunanetra dan tiga orang guru SMPLB. Diperoleh hasil yang menyatakan bahwa pengembangan KIT Praktikum layak dengan memenuhi kategori valid, efektif dan praktis.

\begin{abstract}
Learning Natural Sciences emphasizes providing direct experience to develop students' competencies so that they can explore and understand the natural surroundings through scientific methods which are emphasized in the form of 5M. This study aims to develop an Integrated Instrument Component for blind students at special high schools to support learning mixed materials and solutions that are valid, effective and practical. The basic competencies of blind students in ninth grade at SMPLB ask blind students to make observations and experiments on mixed material and solutions but not with the availability of learning media. This study uses a research and development (R\&D) approach. The approach $(R \& D)$ aims to develop and validate the devices used in schools so that they are ready to work effectively and practically. The resulting Mixed Science and Solution learning tools were valid, effective, and practical for blind students of class IX SMPLB. This is obtained based on the results of the tests from expert of media, material, and teacher who have the specialty of teaching blind students. The results of the test were carried out on five blind children and the responses from blind students and three special shcool teachers. From the data obtained, it can be stated that the development of the KIT Practicum is feasible by meeting the valid, effective and practical categories.
\end{abstract}

\section{Pendahuluan}

Pembelajaran Ilmu Pengetahuan Alam menekankan pada pemberian pengalaman langsung untuk mengembangkan kompetensi peserta didik agar manpu menjelajahi dan memahami alam sekitar melalui metode ilmiah yang ditekankan dalam bentuk 5M (mengamati, menanya, mengumpulkan informasi, mengasosiasikan, dan mengomunikasikan)(Artini, 2019; Yuliati, 2017). Sains merupakan pengetahuan 
yang sistematis dan tersusun secara teratur, berlaku umum (universal), dan berupa kumpulan data hasil observasi dan eksperimen (Artini, 2019; Sari et al., 2021; Sawitri, 2018). Ilmu pendidikan alam terlebih kimia merupakan ilmu yang memungkinkan untuk dilkukannya kegiatan praktikum. Praktikum memungkinkan peserta didik menggunakan semua potensi yang ada pada dirinya (kognitif, afektif, dan psikomotorik) terutama proses mentalnya untuk menemukan sendiri konsep-konsep atau prinsip-prinsip kimia dan proses mental lainnya (Lasia, 2020). Praktikum merupakan salah satu metode pembelajaran yang berfungsi memperjelas konsep melalui kontak dengan alat, bahan, atau peristiwa alam secara langsung, meningkatkan ketrampilan intelektual peserta didik melalui observasi atau pencarian informasi secara lengkap dan selektif yang mendukung pemecahan problem praktikum, melatih dalam memecahkan masalah, menerapkan pengetahuan dan ketrammpilan terhadap situasi yang dihadapi, melatih dalam merancang eksperimen, menginterpretasi data, dan membina sikap ilmiah (Faj et al., 2018; Suryaningsih, 2017). Saat terlibat dalam proses penyelidikan ilmiah, peserta didik dapat mengidentifikasi pertanyaan yang dapat dijawab melalui investigasi ilmiah, gunakan alat dan teknik yang sesuai untuk mengumpulkan, menganalisis, dan menafsirkan data, mengembangkan deskripsi, penjelasan, prediksi, dan model menggunakan bukti, tes penjelasan tersebut terhadap pengetahuan ilmiah saat ini, dan mengomunikasikan ide-ide mereka kepada orang lain (Kizilaslan, 2019).

Komponen Instrumen Terpadu (KIT) merupakan peralatan di mana dapat dikembangkan dan dikemas dalam dalam bentuk kotak kesatuan pengajaran, yang berbentuk menyerupai rangkaian alat yang digunakan menguji keterampilan proses pada bidang studi IPA (Sains) dan dilengkapi dengan petunjuk penggunaannya. KIT IPA (Sains) berfungsi sebagai penyampai pesan agar peserta didik mampu memahami konsep dari kegiatan yang dilakukannya (Rosnita, 2016). Maka dari itu, dapat dikatakan faktor yang penyebabkan peserta didik lebih cepat memahami materi yang diajarkan adalah KIT IPA. Sebagaian besar persentase pengetahuan yang diperoleh peserta didik adalah berasal dari simulasi, pemodelan atau pngalaman belajar, dengan kata lain peserta didik mempraktekkan atau mengalami sendiri baik itu menggunakan bentuk atau wujud asli materi yang diajarkan maupun lewat benda atau kejadian yang dimanipulasi agar mendekati keadaan yang sebenarnya.

Pendidik memiliki tugas mengatur tanggung jawab untuk memastikan bahwa tidak ada peserta didik berkualifikasi penyandang cacat bisa dikecualikan atau dicabut dari manfaat berdasarkan kecacatan mereka (Michael \& Wohlers, 2019). Fakta di lapangan bahwa guru tidak melakukan penilaian kinerja secara autentik pada kegiatan praktikum disebabkan karena penilaian yang dilakukan hanya berdasarkan pengamatan sekilas dan keaktifan peserta didik saja, sehingga penilaian yang dilakukan tidak mencakup keseluruhan kompetensi mata pelajaran kimia yang diharapkan (Kusumaningtyas, 2018). Tunanetra merupakan sebuah istilah umum yang digunakan untuk konsisi seseorang yang memiliki gangguan atau hambatan dalam indera penglihatannya. Pada dasarnya, tunanetra dibagi menjadi dua kelompok, yaitu buta total dan kurang penglihatan (Widiastuti, 2019). Dikatakan blindbila tidak dapat melihat dua jari di mukanya atau hanya melihat sinar atau cahaya yang lumayan dapat dipergunakan untuk orientasi mobilitas. Mereka tidak bisa menggunakan huruf lain selain huruf braille. Sedangkan yang disebut low vision adalah mereka yang bila melihat sesuatu, mata harus didekatkan, atau mata harus dijauhkan dari objek yang dilihatnya, atau mereka yang memiliki pemandangan kabur ketika melihat objek (Widiyawati, 2019). Untuk mengatasi permasalahan penglihatan, para penderita low visionini menggunakan kacamata atau lensa (Khaeroh, 2020). Dampak dari hilangnya fungsi penglihatan maka seseorang yang tunanetra akan berusaha mengandalkan fungsi indera yag lainnya dengan maksimal. Anak dengan kondisi tunanetra memiliki keterbatasan atau bahkan ketidakmampuan dalam menerima rangsangan atau informasi dari luar dirinya melalui indera penglihatannya (Rahmawati, 2018). Dengan demikian, eksplorasi pada anak tunanetra dilakukan dengan mengoptimalkan indera-indera yang lain, seperti perabaan, suara, dan penciuman (Savira et al., 2019).

Anak tunanetra pada dasarnya menyimpan pengalaman khusus seperti halnya anak normal, namun pengalamannya tersebut kurang terintegrasikan. Kosa kata anak tunanetra cenderung merupakan katakata yang denitif. Anak tunanetra mendapat angka yang sama dengan anak normal, dalam hal berhitung, informasi, dan kosa kata namun kurang baik dalam pemahaman dan persamaan (Basri \& Sagala, 2019). Peserta didik dengan tunanetra memiliki rentang kemampuan kognitif yang sama dengan peserta didik lain, mereka memperoleh informasi melalui sensor lain modalitas (pendengaran, sentuhan dan penciuman) dan informasi yang diperoleh mungkin terbatas dan membingungkan (Kizilaslan, 2019). Peserta didik tunanetra atau gangguan penglihatan harus belajar dengan alat indera lain; merasakan, menyentuh, mencium, dan mendengarkan (Fansury et al., 2019). Sebagian besar peserta didik yang tunanetra dan lowvision (BLV) tidak berpartisipasi dalam kegiatan laboratorium atau mereka sangat terbatas sebelum dimasukkan hukum berlaku efektif (Michael \& Wohlers, 2019). Pada anak tunanetra orientasi dan mobilitas memberi kemampuan kepada anak dalam hal mengenali posisi dan melakukan pergerakan berpindah tempat. Orientasi dapat diartikan kemampuan menggunakan indra lain sebagai pengganti indra 
penglihatan, sedangkan orientasi dapat diartikan sebagai kemampuan berpindah tempat (R. Y. Rahmawati \& Sunandar, 2018). Tujuan dari dilakukannya pendidikan untuk tunanetra bukan dari kemampuan kognitif, melainkan untuk melatih kemandirian anak tunanetra (Situmorang \& Mangunsong, 2018).

Praktikum merupakan salah satu proses belajar yang dilaksanakan di laboratorium. Praktikum biasanya dilalukan guna untuk membuktikan teori yang diperoleh (Mujiyanti et al., 2020). Proses kegiatan pembelajaran dapat diperoleh dimana saja dan kapan saja. Salah satunya yaitu dalam pelaksanaan praktikum (S. R. Adawiyah et al., 2020). Fungsi praktikum adalah untuk melengkapi bahan teori yang diterima, untuk mengumpulkan keberanian untuk menemukan fakta ilmiah dari objek lingkungan dan sosial, dan untuk menambah keterampilan dalam memanfaatkan alat (Suleman et al., 2019). kegiatan praktikum peserta didik melakuksan pembelajaran secara langsung, baik itu mengamati, merancang, menimbang, mengukur, mereaksikan yang semuanya melatih keterampilan mereka. Hal tersebut merupakan alasan praktikum sangat penting untuk dilakukan (Purwaningsih, 2019). Menurut pandangan teori konstruktivisme, dalam suatu proses pembentuan pengetahuan harus dilakukan peserta didik itu sendiri dengan aktif melakukan kegiatan, berfikir, menyusun konsep, dan memberikan arti atau makna tentang yang sedang dipelajari (Adawiyah et al., 2019). Sebagaimana yang telah dijelaskan dalam teori konstruktivis bahwa peserta didik harus secara individu menemukan dan menerapkan informasi-informasi kompleks ke dalam situasi lain apabila mereka harus menjadikan informasi itu miliknya sendiri. Pandangan tersebut mengarahkan peserta didik agar lebih aktif dalam pembelajaran mereka sendiri. Maka dibutuhkan pengembangan media pembelajaran untuk mengaktifkan peserta didik. Selain itu, dalam kegiatan pembelajaran diharapkan adanya suasana pembelajaran yang secara aktif dapat mengembangkan potensi diri peserta didik agar tujuan pendidikan nasional tercapai (Andiastutik \& Lutfi, 2017). Peserta didik akan mudah memahami suatu materi ketika dia melakukan suatu aktivitas untuk mempelajarinya, hal ini akan membuat mereka menikmati proses pembelajaran. Pembelajaran yang selama ini dilakukan oleh guru lebih mengutamakan ketercapaian aspek kognitif dan afektif. Peserta didik belum dibiasakan dengan berbagai keterampilan proses sains seperti kegiatan merumuskan masalah, merancang percobaan serta menggunakan alat dan bahan terhadap rancangannya tersebut (Suhanda, 2018).

Pada penelitian sebelumnya mengembangkan model praktikum sains untuk peserta didik tunanetra dikatakan bahwa telah terealisasikan KIT Praktikum untuk peserta didik tunanetra. Keberhasilan dalam penelitian terdahulu tersebut terwujudnya suatu upaya yang bersifat metodologis praktis untuk meningkatkan kualitas pembelajaran sains bagi peserta didik tunanetra. Hasil yang dicapai penelitian tersebut adalah tersusunnya perangkat KIT media pembelajaran praktikum peserta didik tunanera, meningkatkan kemampuan guru dalam melakukan keseluruhan aspek dalam sintaks pembelajaran seperti yang telah dirancang, dan aktifitas guru berfokus dalam kegiatan membimbing peserta didik dalam kegiatan praktikum (Astono, 2010). Dalam pembelajaran IPA materi Campuran dan Larutan dibutuhkan KIT yang disesuaikan dengan keadaan anak tunanetra guna mendukung pembelajaran di sekolah. Dalam kegiatan pra penelitian dan ditemukan bahwa pada materi campuran dan larutan dalam proses pembelajarannya hanya dengan metode guru membacakan dan peserta didik mencoba memahami dari apa yang dibacakan oleh guru. Serta untuk kegiatan percobaan guru biasa menggunakan cara peserta didik merasakan larutan atau campuran dengan meminum dan merasakan, apakah terdapat zat sisa atau tidak. Dengan kesimpulan jika terdapat zat sisa maka termasuk ke dalam campuran. Namun apabila dilihat lebih lanjut, dalam kehidupan sehari-hari tidak semua campuran memiliki zat sisa. Selain itu, tidak semua bahan yang ada dapat di uji dengan cara meminumnya.

Pada penelitian ini, akan diciptakan KIT yang dirangkai dari arduino uno, module sensor cahaya, module audio, dan power bank. Sistem kerjanya menggunakan prinsip sensor cahaya yang apabila sensor menangkap cahaya maka akan disampaikan informasi hasil sensor ke module audio sehinga akan mengeluarkan bunyi kelas sebagai tanda bahwa cahaya telah ditangkap sensor. Maka dalam KIT tersebut juga terdapat rangkaian lampu LED untuk memberikan cahaya yang berfungsi untuk mendeteksi larutan maupun campuran. Cara kerja KIT tersebut jika suatu larutan ataupun campuran dimasukkan ke dalam wadah KIT dan diberikan cahaya dari lampu LED lalu apabila cahaya dapat diteruskan sehingga mengenai sensor cahaya maka modul audio secara otomatis akan mengeluarkan bunyi sebagai tanda bahwa bahan tersebut merupahan larutan karena dapat ditembus cahaya. Sedangkan yang dimasukkan dalam wadah KIT adalah campuran maka cahaya yang diberikan tidak akan dapat terdeteksi oleh sensor cahaya sehingga modul audio akan tetap diam. Namun KIT Praktikum tersebut belum ada dan perlu dikembangkan.

\section{Metode}

Penelitian ini mengikuti rancangan dengan pendekatan research and development (R\&D). pendekatan (R\&D) bertujuan untuk mengembangkan dan memvalidasi perangkat perangkat yang digunakan di sekolah agar bekerja siap pakai efektif, serta praktis (Sugiyono, 2016). Sasaran penelitian ini 
adalah KIT praktikum yang akan dijadikan media pembelajaran campuran dan larutan pelajaran IPA SMPLB kelas IX peserta didik tunanetra. Penelitian ini dilakukan subyek penelitian ini terdiri dari 5 peserta didik tunanetra kelas IX di SMPLB Kalitidu Bojonegoro. Studi lapangan dilaksanakan di SMPLB peserta didik tunanetra. Data dapat diperoleh dari hasil wawancara dengan pihak sekolah mengenai cara pengajaran materi larutan dan campuran yang diberikan kepada peserta didik, serta mengenai media pembelajaran yang diajarkan di SMPLB tunanetra. Selanjutnya dilakukan studi pustaka yang bertujuan memberikan gambaran dan informasi tambahan dari berbagai literasi penelitian sebelumnya sebagai pedoman untuk membantu proses pemecahan masalah dan pengembangan media. Setelah studi dilaksanakan maka proses desain produk dapat dilakukan. Proses desain dilakukan dengan tujuan dapat memberi perhitungan mentah mengenai bahan dan alat yang diperlukan meminimalisir terjadinya pemborosan alat dan bahan serta kegagalan produk. Desain Produk ini masih bersifat hipotetik dimana keefektifannya belum terbukti sehingga perlu dilakukan pengujian untuk mengetahuinya. Pengujian ini dilakukan dengan adanya pengujian tentang kelayakan dengan memenuhi kategori valid, efektif, dan praktis (Fitria et al., 2017). Sesuai kriteria pengembangan KIT Praktikum serata respon peserta didik dan hasil belajar yang diharapaan meningkat.

Desain KIT Praktikum untuk peserta didik tunanetra yang dikembangkan dapat ditelaah oleh ahli media pembelajaran yaitu dosen kimia berpengalaman untuk menilai rancangan produk tersebut. Dalam tahap ini penenlaah diminta meberikan komentar dan saran terhadap produk pada lembar telaah. KIT Praktikum pada materi campuran dan larutan untuk peserta didik kelas IX SMPLB peserta didik tunanetra setelah ditelaah maka kekurangan dari desain akan diketahui. Kekurangan yang ditemukan pada desain produk selanjutnya direvisi berdasarkan kritikan dan saran yang diberikan. Validasi desain dilakukan dengan tujuan untuk melihat dan menilai rancangan produk yang dalam sistem kerja baru ini akan lebih efektif dibandingkan dengan sistem kerja yang lama. Hasil validasi digunakan untuk merevisi dan memperbaiki media yang dikembangkan. Data hasil lembar validasi dianalisis menggunakan kriteria skor kevalidan dengan menggunakan rumus persentase kelayakan. Berdasarkan presentase kevalidan KIT Praktikum materi Campuran dan Larutan sebagai media pembelajaran, dikatakan valid apabila presentasenya $\geq 61 \%$ (Sari, H. V., \& Suswanto, 2017).

Setelah validasi terlaksana maka dilakukan uji coba terbatas. Uji coba dilakukan terhadap KIT Praktikum dengan sensor cahaya yang telah dikembangkan untuk mengetahui kepraktisan. Kepraktisan didasarkan dengan melakukan angket respon kepada peserta didik. Lembar angket di isi oleh peserta didik dengan bantuan guru pendamping setelah menggunakan KIT Praktikum larutan dan campuran materi IPA peserta didik tunanetra. Penilaian ketertarikan, keterbaruan, kebermanfaatan, dan kemudahan peserta didik selama melakukan KIT Praktikum materi Campuran dan Larutan diperoleh berdasarkan skor skala guttman yaitu untuk menjawab "ya" akan diberi skor 1 pada pernyataan positif dan untuk menjawab "tidak" akan diberi skor 0 pada pernyataan negatif. Untuk menguji keefektifan digunakan skor pretest dan postest menggunakan sistem One Group Pretest-postest Design. Analisis data tes hasil belajar peserta didik diperoleh dari skor pretest dan posttest. Lalu skor saat pretest dan skor saat posttes dibandingkan, dan diharapkan memiliki perbedaan yang signifikan. Apabila memiliki perbedaan skor yang besar maka dapat dikatakan bahwa KIT Praktikum tersebut memiliki dampak dalam pemahaman materi peserta didik.

\section{Hasil dan pembahasan}

Pada pengembangan media pembelajaran, sebelum melakukan pengembangan telah dilakukan kegiatan pra penelitian dimana pada kompetensi dasar IPA SMPLB Tunanetra kelas IX dirumuskan 3.3 menelaah campuran dan larutan melalui pengamatan serta pada 4.2 melakukan percobaan untuk membedakan campuran dan larutan menggunakan bahan yang dikenal dalam kehidupan sehari-hari. Kompetensi dasar tersebut meminta peserta didik tunanetra dapat melakukan pengamatan maupun percobaan pada materi campuran dan larutan. Peserta didik dengan tunanetra memiliki rentang kemampuan kognitif yang sama dengan peserta didik lain, mereka memperoleh informasi melalui sensor lain modalitas (pendengaran, sentuhan dan penciuman) dan informasi yang diperoleh mungkin terbatas dan membingungkan (Kizilaslan, 2019). Maka untuk membantu pembelajaran dan meminimalisir adanya kesalahan pemahaman materi maka dikembangkan media pembelajaran KIT Praktikum campuran dan larutan dimana menggunaka sensor cahaya sebagai alat pembantu mengidentifikasi bahan dalam kehidupan sehari-hari termasuk campuran atau larutan. Pada pengembangan media pembelajaran, media KIT Praktikum campuran dan larutan yang telah dirancang sesuai dengan kebutuhan anak tunanetra yang telah dirancang dengan menggunakan fungsi sensor cahaya perlu dilakukan telaah kepada dosen pembimbing dimana dari proses tersebut diberikan komentar atau saran sebagai acuan untuk perbaiakn terhadap media dan instrumen penelitian. 
Setelah proses telaah maka yang dilakukan adalah proses validasi kepada beberapa validator. Validasi tersebut dilakukan dengan tujuan mengetahui kevalidan media KIT Praktikum dengan sensor cahaya yang dikembangkann. Validasi dilakukan berdasarkan kebahasaan, persyaratan isi, dan persyaratan konstruk. Validator yang menjadi penilai kelayakan media KIT Praktikum campuran dan larutan terdiri dari dua dosen kimia yang menilai mengenai pengembangan media dan juga kesesuaian materi campuran dan larutan serta satu guru SMPLB yang khusus mengajar untuk anak tunanetra. Adapun hasil dari validasi yang telah dilakukan oleh masing-masing validator terhadap media KIT Praktikum campuran dan larutan. ditunjukkan pada Tabel 1.

Tabel 1. Hasil data validasi

\begin{tabular}{llcccc}
\hline \multirow{2}{*}{ No. } & Aspek Standar & \multicolumn{3}{c}{ Hasil Persentase (\%) } & \multirow{2}{*}{ Kategori } \\
\cline { 3 - 5 } & Mutu/Indikator & Validator 1 & Validator 2 & Validator 3 & Valid \\
\hline 1. & Kebahasaan & 85 & 75 & 95 & Valid \\
2. & Persyaratan Isi & 100 & 86 & 100 & Valid \\
3. & Persyaratan Konstruk & 84 & 85 & 84 & \\
\hline
\end{tabular}

Berdasarkan Tabel 4 menunjukkan presentase kevalidan KIT Praktikum materi Campuran dan Larutan sebagai media pembelajaran, karena dapat dikatakan valid apabila presentasenya $\geq 61 \%$ (Sari, $\mathrm{H}$. V., \& Suswanto, 2017). Dari tiga validator yang berpartisipasi setiap aspek memiliki hasil persentase yang mengatakan media KIT Praktikum valid. Validasi dilakukan oleh ahli sesuai bidangnya masing-masing di mana hasil validasi tersebut apabila dinyatakan valid dapat di lanjutkan ke tahap selanjutnya (Indriani et al., 2018). Keberhasilan penerapan media pembelajaran KIT Praktikum campuran dan larutan ini bukan hanya ditunjukkan makin meningkatnya skor peserta didik, tetapi juga respon positif peserta didik dan guru pendamping. Tujuan dari dilakukannya angket respon untuk peserta didik adalah guna mengetahui ketertarikan peserta didik terhadap KIT, keterbaruan KIT, kebermanfaatan KIT, serta kemudahan dalam penggunaan KIT tersebut. Secara lebih jelas rekapitulasi respon peserta didik tertera dalam Tabel 2.

Tabel 2. Hasil rekapitulasi respon peserta didik

\begin{tabular}{llcc}
\hline No. & \multicolumn{1}{c}{ Aspek } & Persentase(\%) & Kategori \\
\hline 1. & $\begin{array}{l}\text { Ketertarikan terhadap KIT Praktikum sebagai media } \\
\text { pembelajaran }\end{array}$ & 90 & Setuju \\
2. & Keterbaruan KIT Praktikum campuran dan larutan & 93 & Setuju \\
3. & Kebermanfaatan KIT Praktikum campuran dan larutan & 100 & Setuju \\
4. & $\begin{array}{l}\text { Kemudahan dalam menggunakan KIT Praktikum } \\
\text { campuran dan larutan }\end{array}$ & 80 & Setuju \\
\hline
\end{tabular}

Berdasarkan Tabel 5 tampak bahwa respon peserta didik terhadap KIT Praktikum campuran dan larutan sangat positif. Dari analisis skala guttman, titik kesesuaian yang didapat di atas $50 \%$ berarti setuju (Atikah, 2019). Pada angket yang diberikan persentase dari ke empat aspek yang diberikan memiliki skor di atas 50\% dimana artinya responden setuju dengan aspek-aspek yang ditanyakan dalam angket dan terbantukan dalam memahami materi serta pengalaman baru melakukan percobaan dalam mata pelajaaran IPA. Selanjutnya rekapitulasi respon guru pendamping sebanyak tiga orang tertera dalam Tabel 3.

Tabel 3. Hasil rekapitulasi respon peserta didik

\begin{tabular}{clcc}
\hline No. & \multicolumn{1}{c}{ Pertanyaan } & Persentase (\%) & Kategori \\
\hline 1. & $\begin{array}{l}\text { Peserta didik dapat mengoprasikan KIT Praktikum } \\
\text { campuran dan larutan dengan benar dan sesuai } \\
\text { petunjuk }\end{array}$ & 100 & Setuju \\
2. & $\begin{array}{l}\text { Peserta didik terpusat perhatiannya pada KIT } \\
\text { Praktikum campuran dan larutan } \\
\text { 3. } \quad \begin{array}{l}\text { Peserta didik melakukanpercobaan dengan jujur saat } \\
\text { menggunakan KIT Praktikum campuran dan larutan }\end{array}\end{array}$ & 100 & Setuju \\
4. & $\begin{array}{l}\text { Kemudahan dalam menggunakan KIT Praktikum } \\
\text { campuran dan larutan } \\
\text { Peserta didik aktif melakukan proses pembelajaran } \\
\text { yang sedang berlangsung }\end{array}$ & 100 & Setuju \\
\hline
\end{tabular}




\begin{tabular}{clcc}
\hline No. & \multicolumn{1}{c}{ Pertanyaan } & Persentase (\%) & Kategori \\
\hline 6. & $\begin{array}{l}\text { Peserta didik dapat melakukan praktikum tanpa } \\
\text { bantuan guru }\end{array}$ & 66,7 & Setuju \\
7. & $\begin{array}{l}\text { Peserta didik kesulitan saat melakukan praktikum } \\
\text { yang ada dalam KIT Praktikum pada materi } \\
\text { campuran dan larutan }\end{array}$ & 66,7 & Setuju \\
$\begin{array}{l}\text { Peserta didik mendengarkan materi dan prosedur } \\
\text { ketika tidak mampu melakukan praktikum }\end{array}$ & 100 & Setuju \\
\hline
\end{tabular}

Berdasarkan Tabel 3 tampak bahwa respon guru pendamping terhadap adanya KIT Praktikum campuran dan larutan sangat positif. Dari analisis skala guttman, titik kesesuaian yang didapat di atas $50 \%$ berarti setuju. Pada angket yang diberikan persentase dari ke empat aspek yang diberikan memiliki skor di atas $50 \%$ dimana artinya responden setuju atas pertanyan yang diberikan pada angket di mana menyatakan tentang kemandirian, perhatian, kejujuran, keaktifan, dan kemudahan peserta didik (Atikah, 2019). Low vision mengacu pada kehilangan penglihatan yang signifikan, meskipun orang tersebut mungkin memakai lensa korektif (Widiyawati, 2019). Dilakukan penelitian kepada lima anak karena jumlah anak tunanetra pada SMPLB Kalitidu Bojonegoro sangat terbatas. Media yang dikembangkan merupakan KIT Praktikum dimana dalam KIT tersebut menggunakan prinsip yaitu apabila suatu larutan diberikan cahaya maka cahaya tersebut dapat menembus larutan sedangkan apabila suau cahaya diberikan pada campuran maka cahaya tersebut akan dibelokkan dan tidak dapat menembus campuran tersebu. Dari prinsip cahaya maka dirancang suatu KIT yang terdiri dari sensor cahaya yang dirangkai denagn arduino uno dan modul audio. Pada perakitannya dilakukan dengan memberikan bahasa pemrograman pada arduino uno yang berfungsi memberikan perintah untuk sensor cahaya dan module audio. Maka dalam KIT tersebut juga terdapat rangkaian lampu LED untuk memberikan cahaya yang berfungsi untuk mendeteksi larutan maupun campuran. Cara kerja KIT tersebut apabila suatu larutan ataupun campuran masukkan ke dalam wadah KIT lalu di berikan cahaya. Apabila cahaya dapat diteruskan sehingga mengenai sensor cahaya maka modul audio secara otomatis akan mengeluarkan bunyi sebagai tanda bahwa bahan tersebut merupahan larutan karena dapat ditembus cahaya. Sedangkan apabila campuran yang dimasukkan maka cahaya yang diberikan tidak akan dapat terdeteksi oleh sensor cahaya sehingga modul audio akan tetap diam. KIT telah dilengkapi oleh audio player untuk memberikan instruksi apa yang harus dilakukan peserta didik saat melakukan percobaan dengan itu dapat meminimalisir bantuan guru sehingga peserta didik dapat dengan mandiri melakukan percobaan. Seluruh alat praktikum telah di ubah menjadi voice equipment atau berbentuk audio. Hal tersebut sesuai dengan teori bahwa tunanetra memiliki rentang kemampuan kognitif yang sama dengan peserta didik lain, mereka memperoleh informasi melalui sensor lain modalitas (pendengaran, sentuhan dan penciuman) (Praptaningrum, 2020). Termasuk juga LKPD yang digunakan untuk mengetahui kemampuan peserta didik dalam melakukan praktikum telah disertakan dalam bentuk audio. Buku dengan audio dapat membantu peserta didik tunannetra dalam situasi apappun tanpa bantuan orang lain dalam menggunakan materi pendidikan (Fansury et al., 2019). LKPD yang disertakan tidak dibuat dalam bentuk huruf braile karena dalam kegitan praktikum didapatkan informasi bahwa dalam keseharian peserta didik belum lancar dalam membaca huruf braile sehingga menggunakan metode audio sangat sesuai dengan peserta didik tunanetra di SMPLB Kalitidu. LKPD yang disertakan sesuai dengan teori konstruktivis bahwa peserta didik diharuskana dapat secara mandiri menemukan dan menerapkan informasi kompleks kedalam suatu situasi (Muslihah, 2018). Sehingga LKPD tersebut juga dapat melatihkan peserta didik dalam menemukan informasi secara mandiri melalui kegitan praktikum menggunakan KIT Praktikum campuran dan larutan yang telah dikembangkan. Seperti yang dikatakan di atas, bahwa pesrta didik tunanetra memiliki angka yang sama dengan anak normal dalam hal berhitung, informasi dan kosa kata meskipun kurang baik dalam pemahaman dan persamaan (Kizilaslan, 2019).

Proses mendapatkan hasil perbedaan pemahaman diuji dengan mengguanakn kegiatan pretest dan posttest. Sebelum melakukan Uji coba maka dilakukan uji pretest selanjutnya dilakukan kegiatan praktikum pada media KIT Praktikum dilakukan dengan menggunakan bahan sehari-hari sebanyak enam bahan. Sebelum melakukan praktikum dilakukan pembekalan materi terlebih dahulu. Proses percobaan dilakukan dengan bantuan audio player yang berisikan pengenalan bagian-bagian KIT, tatacara menyiapkan KIT, tatacara menyiapkan larutan, dan tatacara penggunaan KIT untuk praktikum. Kegiatan dilakukan sesuai dengan tahap-tahap yang terdapat pada LKPD. Seperti yang tercantum dalam LKPD tahap satu merupakan diskusi dimana peserta didik menyebutkan definisi dari masing-masing larutan dan campuran dengan bahasa peserta didik sendiri. Tahap dua merupakan penyampaian hasil diskusi beserta contoh-contoh dari larutan dan campuran. Selanjutnya tahap tiga adalah pengumpulan data dimana disini proses percobaan dimulai. Percobaan dilakukan secara individu dan mandiri oleh peserta didik tanpa bantuan guru. Pada tahap ke empat dilakukan mengklasifikasikan bahan yang di uji pada tabel sesuai dengan hasil percobaan 
yaitu larutan atau campuran. Cara pengisian ini peserta didik akan dibantu oleh guru untuk memberi tanda cawang pada tabel sesuai dengan jawaban peserta didik. Tahap lima merupakan tahapan menyimpulkan dimana peserta didik akan menyimpulkan dari apa yang didapatkan pada hasil percobaan. Terakhir tahap enam yaitu tahapan mengkomunikasikan hasil percobaan di depan kelas. Setelah melaksakan semua tahapan maka peserta didik satu persatu akan diuji pemahaman materi setelah melakukan percobaan dalam sesi posttest. Hasil posttest dapat dilihat pada Gambar 1.

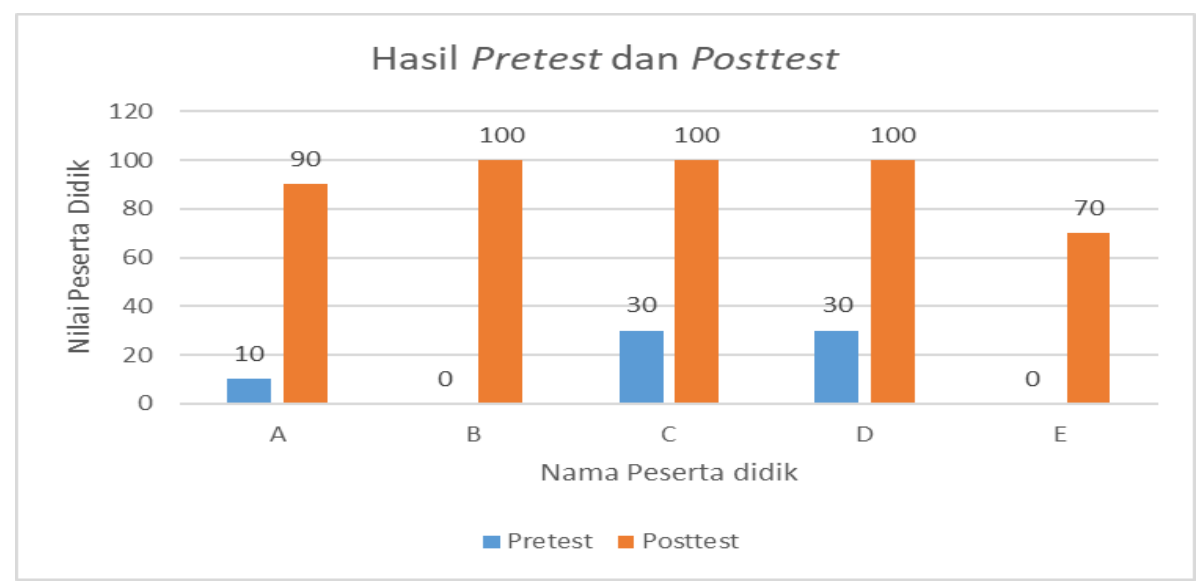

Gambar 1. Perbandingan hasil pretest dan posttest

Tabel dan grafik tersebut dapat memperlihatkan perbedaan pemahaman yang terjadi setelah melakukan praktikum dan sebelum melakukan praktikum. Pada saat posttest didapatkan skor yang lebih tinggi dibandingkan saat pretest. Maka dari itu dapat disimpulkan bahwa pemahaman peserta didik meningkat setelah dilakukan kegiatan praktikum menggunakan KIT Praktikum campuran dan larutan. LPMP pada metode praktikum dalam pembelajaran ilmu pengetahuan alam bahwa praktikum merupakan salah satu metode pembelajaran yang dapat memperjelas konsep melalui kontak dengan alat, bahan, atau peristiwa alam secara langsung, menunjang segi ketrampilan intelektual peserta didik dengan observasi dan pencarian informasi secara lengkap dan selektif serta dapat memecahkan masalah praktikum, melatih dalam memecahkan masalah, menerapkannya dalam situasi yang dihadapi, melatih merancang praktikum, menginterpretasikan data, dan melatihkan sikap ilmiah (Suryaningsih, 2017).

\section{Simpulan dan saran}

Media pembelajaran materi Campuran dan Larutan yang dikembangkan dapat dinyatakan valid, efektif, dan praktis. Hal ini diperoleh berdasarkan hasil uji ahli media, materi, dan guru yang memiliki kekhususan mengajar peserta didik tunanetra. Hasil uji coba pada lima anak tunanetra diperoleh persentase penilaian peserta didik dengan selisih yang signifikan sehingga dapat disimpulkan adanya peningkatan pemahaman peserta didik pada materi campuran daan larutan. Peserta didik memiliki ketertarikan terhadap KIT. keterbaruan KIT disetujui oleh peserta didik, kebermanfaatan KIT, serta kemudahan peserta didik dalam penggunaan KIT tersebut. Maka dapat dikatakan bahwa komponen instrumen terpadu atau disebut juga KIT yang dikembangkan untuk peserta didik tunanetra pada Sekolah Menengah Luar Biasa dalam menunjang pembelajaran materi campuran dan larutan yang dikembangkan merupakan perangkat pembelajaran yang valid, efektif dan praktis.

\section{Daftar Rujukan}

Adawiyah, R., Sukaryawan, M., \& Mujamil, J. (2019). Pengembanganmodul Laju Reaksi Berbasis Konstruktivisme Lima Fase Needham. Jurnal Penelitian Pendidikan Kimia, 6(1). https://doi.org/10. 36706/jppk.v6i1.8484.

Adawiyah, S. R., Hakim, A., \& Hadisaputra, S. (2020). Pengembangan Modul Praktikum Kimia Bahan Alam Berbasis Generik Sains: Isolasi Fenobarbiton dari Kulit Batang Pohon Api-api (Avicennia marina). Chemistry Education Practice, 3(2), 84. https://doi.org/10.29303/cep.v3i2.1994.

Andiastutik, E., \& Lutfi, A. (2017). Pengembangan Permainan Diamond Chemistry Adventure Sebagai Media Pembelajaran Pada Materi Pokok Hidrokarbon Kelas Xi Sma (Development of Diamond Chemistry Adventure Game As a Learning Media on Hydrocarbon Matter for Eleventh Grade Senior High 
School). UNESA Journal of Chemical Education, 6(2), 212-218. https://jurnalmahasiswa. unesa.ac.id/index.php/journal-of-chemical-education/article/view/20214.

Artini, P. C. (2019). Pengembangan Perangkat Pembelajaran Pada Pokok Bahasan Larutan Penyangga Dengan Pola Deduktif. Jurnal Pendidikan Kimia Indonesia, 3(2), 77-84. https://ejournal.undiksha .ac.id/index.php/JPK/article/view/21131.

Astono, J. (2010). Pengembangan Model Praktikum Sains Untuk Siswa Tunanetra Melalui Pendekatan Konstruktivis Serta Aplikasinya Pada Pendidikan Inklusif. Jurnal Cakrawala Pendidikan, 1(1). https://doi.org/10.21831/cp.v1i1.217.

Atikah, D. (2019). Program Hibah Jalan Daerah ( PHJD ) dan Keterlibatan Perempuan dalam Pekerjaan Konstruksi Jalan. Spirit Pro Patria, 5(2), 135-137. https://jurnal.narotama.ac.id/index.php/patria /article/view/1003/648.

Basri, A. S. H., \& Sagala, H. B. (2019). Model Bimbingan Konseling Islam Bagi Siswa Tunanetra. Jurnal Bimbingan, Penyuluhan, Dan Konseling Islam, 2(1). https://doi.org/10.15575/alisyraq.v2i1.37.

Dalman, \& Mardiana. (2019). The Development of Character Based Group Investigation Learning Models for Blind Students. Journal of Physics: Conference Series, 1179(1), 1-5. https://doi.org/10.1088 /1742-6596/1179/1/012053.

Faj, N. A., Fakhri, J., \& Yusandika, A. D. (2018). Efektifitas Model Pembelajaran Quantum Teaching dengan Metode Praktikum terhadap Hasil Belajar Peserta Didik. Indonesian Journal Of Science and Matematic Education, 1(2). https://doi.org/10.24042/ijsme.v1i2.2771.

Fansury, A. H., Lutfin, N., \& Arsyad, S. N. (2019). Audio Books As Teaching Media To Blind Students In Learning EFL. Journal of Education, 1(1). https://doi.org/10.52208/klasikal.v1i1.4.

Fitria, A. D., Mustami, M. K., \& Taufiq, A. U. (2017). Pengembangan Media Gambar Berbasis Potensi Lokal Pada Pembelajaran Materi Keanekaragaman Hayati Di Kelas X Di SMA 1 PITU RIASE KAB. SIDRAB. Jurnal Pendidikan Dasar, 4(2). http://journal.uinalauddin.ac.id/index.php/auladuna/article /download/5176/4669.

Indriani, E., Sahputra, R., \& Hadi, L. (2018). Pengembangan Media Komponen Instrumen Terpadu (KIT) Ikatan Kimia. Journal FKIP Untan, 6(10). https://jurnal.untan.ac.id/index.php/jpdpb/article/view /22695/18012.

Khaeroh, I. (2020). Pelaksanaan Pendidikan Inklusif Untuk Siswa Dengan Hambatan Penglihatan ( Low Vision ) Di Sekolah Dasar. Jurnal Pendidikan Inklusi, 4(1), 11-21. https://journal.unesa.ac.id /index.php/ji/article/view/11328/4741.

Kizilaslan, A. (2019). Linking Theory to Practice: Science for Students with Visual Impairment. Science Education International, 30(1), 56-64. https://doi.org/10.33828/sei.v30.i1.7.

Kusumaningtyas, P. (2018). Pengembangan Instrumen Penilaian Kinerja Untuk Mengukur Kompetensi Siswa dalam Kegiatan Praktikum Kimia di SMA/K. Jurnal Inovasi Pendidikan Kimia, 12(2), 2128 2136. https://journal.unnes.ac.id/nju/index.php/JIPK/article/view/15470.

Lasia, K. (2020). Peningkatan Keselamatan Kerja Di Laboratorium Melalui Pelatihan Penggunaan Bahan Berwawasan Lingkungan. Jurnal Pengabdian Kepada Masyarakat, 9(1). https://doi.org/ 10.23887/jwl.v9i1.21434.

Lestari, E. S. (2016). Buku Siswa SMPLB Tunanetra Kelas IX. Direktorat Pembinaan Pendidikan Khusus dan Layanan Khusus Pendidikan Dasar dan Menengah.

Matanari, C., Gaol, R. L., \& Simarmata, E. (2020). Hubungan Pendidikan Karakter Terhadap Perkembangan Sosial Anak Sekolah Dasar. Journal of Educational Review and Research, 6(2), 294-300. https://doi.org/10.31949/educatio.v6i2.435.

Michael, J. M., \& Wohlers, H. D. (2019). Tools Enabling a Student Who Is Blind in a Liberal Arts Chemistry Laboratory Course. Journal of Science Education for Students with Disabilities, 22(1), 1-11. https: //doi.org/10.14448/jsesd.11.0010.

Mujiyanti, A. R., Hakim, A., \& Hadisaputra, S. (2020). Pengembangan Modul Praktikum Generik Sains Kimia Bahan Alam: Isolasi Asam Anakardat dari Kulit Biji Jambu Mete. Chemistry Education Practice, 3(2), 91. https://doi.org/10.29303/cep.v3i2.1989.

Muslihah, N. N. (2018). Pembelajaran Soal Cerita Hitung Campuran Melalui Pendekatan Konstruktivisme. Al-Aulad: Journal of Islamic Primary Education, 1(1). https://doi.org/10.15575/al-aulad.v1i1.2332.

Praptaningrum, A. (2020). Penerapan Bahan Ajar Audio Untuk Anak Tunanetra Tingkat Smp Di Indonesia. Jurnal Teknologi Pendidikan, 5(1). https://doi.org/10.33394/jtp.v5i1.2849.

Pratiwi, S. N., Cari, C., \& Aminah, N. S. (2019). Pembelajaran IPA Abad 21 dengan Literasi Sains Siswa. Jurnal Materi Dan Pembelajaran Fisika (JMPF), 9(1), 34-42.

Purwaningsih, O. (2019). Pengembangan Panduan Praktikum Virtual Larutan Penyangga Untuk Menunjang Pelaksanaan Praktikum Nyata. Chemistry in Education, 7(2). https://doi.org/10.15294/IJCS.V7I2.21466. 
Rahmawati, H. K. (2018). Kegiatan Pengembangan Diri Dalam Menggali Potensi Anak Tunanetra Di Panti Tunanetra Aisyiyah Ponorogo. Konseling Edukasi "Journal of Guidance and Counseling," 2(1). https://doi.org/10.21043/konseling.v2i1.4463.

Rahmawati, R. Y., \& Sunandar, A. (2018). Peningkatan Keterampilan Orientasi dan Mobilitas melalui Penggunaan Tongkat bagi Penyandang Tunanetra. Jurnal ORTOPEDAGOGIA, 4(2), 100-103. https://doi.org/10.17977/um031v4i12018p100.

Rosnita. (2016). Keterampilan Guru Dalam Melaksanakan Praktikum Dengan Menggunakan Komponen Instrumen Terpadu (KIT) IPA SD. Jurnal Pengajaran MIPA, 21(1), 103 - 106. https://doi.org/ 10.18269/jpmipa.v21i1.671.

Sari, H. V., \& Suswanto, H. (2017). Pengembangan Media Pembelajaran Berbasis Web Untuk Mengukur Hasil Belajar Siswa Pada Mata Pelajaran Komputer Jaringan Dasar Program Keahlian Teknik Komputer Dan Jaringan. Journal Pendidikan: Teori, Penelitian, Dan Pengembangan, 2(7). https: //doi.org/10.17977/jptpp.v2i7.9734.

Sari, G. K., Indrawati, I., \& Gani, A. A. (2021). Model Pembelajaran Berbasis Masalah (Problem Based Learning/Pbl) Dengan Media Gambar Kejadian Fisika Pada Pembelajaran IPA Fisika Di SMP. Jurnal Pembelajaran Fisika, 3(2). https://doi.org/https://doi.org/10.19184/jpf.v3i2.23269.

Savira, S. I., Wagino, W., \& Laksmiwati, H. (2019). Apa yang Berbeda? Kemampuan Kognitif pada Anak Tunanetra Tanpa Pengalaman Visual (Congenital Visual Impairment). JPI (Jurnal Pendidikan Inklusi), 3(1), 20. https://doi.org/10.26740/inklusi.v3n1.p20-39.

Sawitri. (2018). Upaya Meningkatkan Penguasaan Siswa Pada Pembelajaran Sains Dengan Metode Eksperimen Dan Kerja Kelompok Serta Metode Penugasan Pada Bahasa Indonesia. Jurnal Pendidikan Sosial, Sains, Dan Humaniora, 4(1). https://doi.org/10.24014/suara\%20guru.v4i1.5583.

Setiawan, I. d. (2018). Profil Pembelajaran Kimia Berbasis Kurikulum 2013 Di Kota Gorontalo Dan Kota Surakarta Kelas X Tahun Ajaran 2016/2017. Jurnal Inovasi Pendidikan Kimia, 12(1), 2039-2054. https://journal.unnes.ac.id/nju/index.php/JIPK/article/view/13296.

Situmorang, D. D. B., \& Mangunsong, F. (2018). Penerapan Music Therapy Berbasis Cognitive Behavior Therapy (Cbt) Bagi Individu Dengan Visual Impairment, Bagaimana? JPI (Jurnal Pendidikan Inklusi), 2(1), 39. https: //doi.org/10.26740/inklusi.v2n1.p39-58.

Sugiyono. (2016). Metode Penelitian Kuantitatif, Kualitatif, dan R\&D. Alfabeta Bandung.

Suhanda. (2018). Penerapan Pembelajaran Kimia Berbasis Proyek Untuk Meningkatkan Keterampilan Proses Sains Siswa Kelas X Sma Negeri 2 Purworejo. Jurnal Inovasi Pendidikan Kimia, 12(2), 2137 2148. https://journal.unnes.ac.id/nju/index.php/JIPK/article/view/15471.

Suleman, M., Sugiyarto, K. H., \& Ikhsan, J. (2019). Development of Media Three-dimensional (3D) Visualization using Virtual Reality on Chemistry Education. Journal of Physics: Conference Series, 1397, 012034. https://doi.org/10.1088/1742-6596/1397/1/012034.

Suryaningsih, Y. (2017). Pembelajaran Berbasis Praktikum Sebagai Sarana Siswa untuk Berlatih Menerapkan Keterampilan Proses Sains dalam Materi Biologi. Journal of Science and Biology Education, 2(2). https://doi.org/10.31949/be.v2i2.759.

Widiastuti, N. L. G. K. (2019). Model Layanan Pendidikan Bagi Anak Berkebutuhan Khusus Yang Mengalami Kecacatan Fisik. Jurnal Ilmiah Ilmu Sosial, 5(1), 46. https://doi.org/10.23887/jiis. v5i1.18779.

Widiyawati, A. T. (2019). Kajian Literasi Media Digital Library Universitas Brawijaya (Studi Kasus pada Mahasiswa Tuna Netra Universitas Brawijaya). Tik Ilmeu : Jurnal Ilmu Perpustakaan Dan Informasi, 3(1), 1. https://doi.org/10.29240/tik.v3i1.617.

Yuliati, Y. (2017a). Literasi Sains Dalam Pembelajaran IPA. Jurnal Cakrawala Pendas, 3(2), 21-28. https://doi.org/http://dx.doi.org/10.31949/jcp.v3i2.592.

Yuliati, Y. (2017b). Miskonsepsi Siswa Pada Pembelajaran IPA Serta Remediasinya. Journal of Science and Biology Education, 2(2). https://doi.org/http://dx.doi.org/10.31949/be.v2i2.1197. 